\title{
Biotechnology: A Boon Against COVID-19 Pandemic
}

\author{
Shreya M. Oza \\ Shree Swaminarayan Institute of Management and IT, Porbandar, Gujarat, India
}

\section{ABSTRACT}

Biotechnology Industry has emerged as one of the key technologies for the transition to a carbon free society, providing health protection, food and energy, and solving important social issues such as environmental protection. In addition, in recent months, biotechnology has been fighting of global COVID-19 pandemic to help and understand how the body's protection against infectious pathogens work. The purpose of this study is to know that how Biotechnology plays an important role in contributing to the current state of the coronavirus. Like this, much effort has been made to develop therapeutic responses to the virus. This paper helps to identify that Biotechnology is one of the modules by which covid19 can be understood properly, treated and prevention can be taken by vaccines. Biotechnology will play an important role in future societies to prevent and contain potential pathogens. COVID-19 is thus highlighting the importance of the biotechnology field. Today, leaders from across the globe are leaning on biotechnology and pharmaceutical companies with hopes of possible solutions for the COVID-19 pandemic that range from diagnostic analyses and therapeutics to preventive vaccines. India is becoming more autonomous and trying to develop better and more unique technologies because India is a young country full of highly skilled resources and "Make in India" can also offer great opportunities for biotech companies and the tech industry. Indian Biotechnologists, researchers and manufacturers have accepted this challenge and have already made major progress against the COVID-19 attack. This paper can easily conclude that the biotechnology profession is very promising, biotechnology scholars not only achieve their research and innovation goals, but also contribute to the country, especially humanity. Biotechnology has proven its importance as the savior of mankind in the 21st century. Thus, we can say that Biotech Industry act as a Boon against Covid-19 Pandemic.

\section{KEY WORDS: BIOTECHNOLOGY, COVID-19, DRUGS, VACCINES, TREATMENT, RESEARCH, PHARMACEUTICAL} INDUSTRIES.

\section{INTRODUCTION}

Biotechnology has grown exponentially without new research and many areas of application in our daily lives from food production to drug development to pollution waste disposal. The COVID-19 pandemic provides a unique opportunity for biotechnologists around the world to face that this challenge head-on. The world is now working in the field of biotechnology to create solutions that help people cope and overcome the current crisis. Diseases the biotechnology industry, including governments research institute and pharmaceutical companies, is fighting this battle by working together to

Biosc Biotech Res Comm P-ISSN: 0974-6455 E-ISSN: 2321-4007

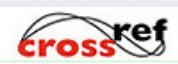

Identifiers and Pagination

Year: 2021 Vol: 14 No (9) Special Issue

Pages: 205-211

This is an open access article under Creative

Commons License Attribn 4.0 Intl (CC-BY).

DOI: http://dx.doi.org/10.21786/bbrc/14.9.39 develop diagnostic tools, drugs and vaccines. In this way biotechnology has evolved into a pioneering technology in the fight against COVID-19. Indian research institute and the biotechnology industry are in control of the proceedings. The highly contagious novel corona virus COVID-19 originated in China but has spread to most countries around the world. It is growing rapidly in a country that threatens the lives of millions of people.

Most people infected with the COVID-19 virus have mild to moderate respiratory illness and recover without special treatment. The elderly and those with underlying medical conditions such as cardiovascular disease, diabetes, chronic respiratory disease and cancer are more likely to develop serious illness. Almost everyone has been directly or indirectly affected by this epidemic. Central and state government, healthcare workers, nurses, paramedics, police basic necessities providers and pharmacists continue to work to greatly support humanity. But the question many people are thinking right now is when and how to end it. All other service providers support this behaviour from the beginning but a group of people are

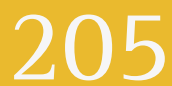


working 24 hours a day to develop suitable demo tools and vaccines for COVID-19. This epidemic has shed light on other areas of scientific research. From diagnosis and treatment to vaccine development everything is in the field of biotechnology (Donald et al., 2021).

\section{Main Body Of Paper:}

What Is Biotechnology?: Biotechnology consists of applying the biological Systems present in living things developing technologies using living organisms themselves and transforming these technologies into other. This includes use in a variety of fields, from agriculture to medical. It includes not only areas related to Life, but all areas where information obtained from biological aspects of living things can be applied. Biotechnology is a field the develops technologies in various fields using living humans for the sustainable development of humanity. All these inspirational stock exchange like Wall Street, one of the most successful sectors of the 2019 NASDAQ Composite Index.

What Was Covid-19 Pandemic?: On 31st December 2019, WHO was informed of cases of pneumonia of unknown cause in Wuhan City, China. A novel Coronavirus was recognized as the cause by Chinese authorities on 7th January, 2020 and was provisionally named "2019nCov". First Covid-19 case distinguished on 27th January, 2020. Many people were affected. As communities started to reopen bars, restaurants and stores during the spring and summer of 2020, people were reasonably eager to be able to go out and restart some of their regular activities. There are two more reasons why the second wave spreads like wildfire (Maria 2010).

People's indifference to Covid-19 prevention measures, such as not wearing masks, washing hands, and not using disinfectants. Large congregations, especially during elections and certain events. This new SARSCOV mutation has learned to evade highly contagious antibodies, so the second wave of coronavirus was curious. Even 18-45 years old, who are thought to have strong immunity, are susceptible. This group is classified as a COVID-19 super expander. They are the people who should get out the most. And when they go home with the infection, they soon spread the disease to others in the house/building/housing company. This new strain of COVID-19 has also infected children. The biotechnology and pharmaceutical industries must play an important role in addressing this global crisis.

Uses And Applications Of Biotehnology: Biotechnology innovations are already part of our daily lives and can be found in many places, including pharmacies and supermarkets. In addition, in recent months, biotechnology has been fighting of global COVID19 pandemic to help decipher the viral genome and understand how the body's defense against infectious pathogens work. Standing at the forefront of Therefore, biotechnology will play an important role in future societies to prevent and contain potential pathogens.
Figure 1.1 Applications of Biotechnology

Source: Environmental Biotechnology: Achievements, Opportunities and Challenges < Maria Gavrilescu (2010), Dynamic Biochemistry, Process Biotechnology and Molecular Biology 4 (1), 1-36 ${ }^{\circ 2010}$ Global Science Books >

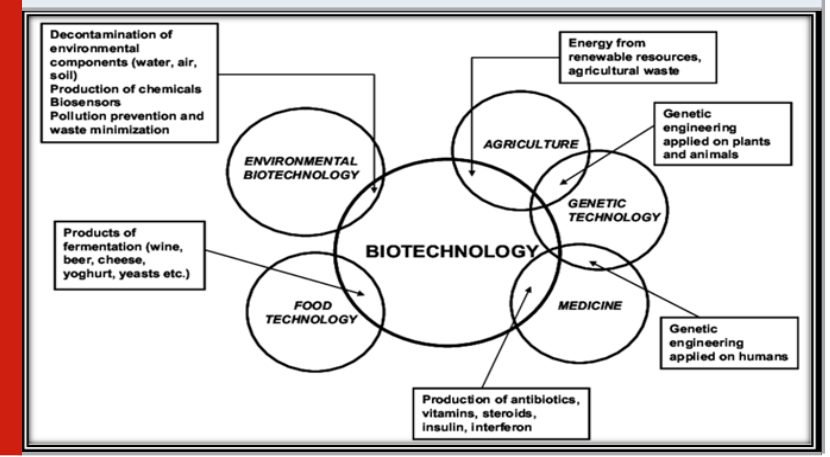

Biotechnologists \& Covid 19 Pandemic: Role Of The Biotech Industry: Biotechnology is a front runner in the encounter in contradiction of covid-19 in India. India's biotechnology industry is anticipated to attain USD 63 billion in 2019 and USD 150 billion in 2025 at a CAGR of $16.4 \%$ by 2025 , the contribution of the Indian biotechnology industry to the global biotechnology market is anticipated to increase from 3\% in 2017 to $19 \%$. The Government of India is expanding its assistance to young researchers and entrenched businesses and institutions to find potential solutions. The Central Government Science and Technology Council (DST-SERB), the Faculty of Biotechnology and the Biotechnology sector Research support Committee (DBT-BIRAC) have solicited applications for the COVID19 Research Consortium. In addition, Asian Institute of Gastroenterology, Hyderabad is witnessing what could be a milestone in treatment of coronavirus disease and they found single-dose drug cocktail of monoclonal antibodies for Covid-patients and after 1 week, the virus disappeared when they did RT-PCR-said by Dr, Reddy (Chair person.)

Recent investment and developments of Biotechnology Industry in Covid-19:

o In September 2020, Aurobindo Pharma announced it would partner with BIRAC to develop a vaccine for COVID-19. The company is developing the vaccine through its US subsidiary Auro Vaccines.

o In November 2020, a trilateral memorandum of understanding was signed between the Serum Institute of India and the pharmaceutical company Beximco Pharmaceuticals. Oxford/ AstraZeneca is based in Bangladesh and the Government of Bangladesh for the purchase of a COVID-19 vaccine.

o In January 2021, ZyCoV-D, the first DNA vaccine candidate developed by Zydus Cadila for COVID-19 
in india, underwent a three-phase clinical trial with approval from Zydus Cadila (DCGI). The applicants have been supported by the National Biopharma Mission (NBM) under the auspices of BIRAC and the Department of Life Engineering of the Government of India. Bharat Biotech plans to produce 700 million times COVID19 vaccine by 2021 in January 2021. The company announced that it plans to set up four facilities and manufacture 200 million times in Hyderabad and 500 million times including Hyderabad.

o In March, 2021, global science company Cytiva and the Telangana government collaborated to open 10,000 square feet. Fast Trak Labs speeds up and drives the need to extend the local BIOS.

o In March, 2021 Gland Pharma Ltd, announced that it would produce 225 million volumes of the Sputnik V COVID-19 vaccine by the third quarter of 2021. In February 2021, the Indian government announced a number of initiatives, including the creation of biotechnology, a study of 10 public universities. Umbrella structures have been formed in nine cities for better coordination between the common industrial pole (URJIT) and the RandD institutions, with an emphasis on priority promotion regions by country (NRF) confirmed by the Research Foundation in January 2021, Biocon Biologics, the biosimilars division of Biocon, was Rs from $A D Q$ an Abu Dhabi sovereign wealth fund. Received an investment of 555 crore ( $\$ 75$ million).

o Bharat Biotech plans to produce 10 vaccines, including malaria and COVID-19 and the next unit plans to invest 300 million rupees (\$45.4 million) in Bhubaneswar in Odisha. In September 2020, the Sree Chitra Trinal Institute of Medical Science in Thiruvananthapuram announced that it would work with the Kerala state government to build a 260 million yuan (US\$35.42 million) medical equipment park in Tonnakar (Thivananthapuram).

Figure 1.2: Biotechnology Research in World

Source: A brief overview of global biotechnology, Donald K. Martin, Oscar Vicente, Tommaso Beccari, Miklós Kellermayer, Martin Koller, Ratnesh Lal, Robert S. Marks, Ivana Marova, Adam Mechler, Dana Tapaloaga, Polona Žnidaršic-Plazl \&t Munis Dundar (2021), Biotechnology \&t Biotechnological Equipment, ISSN: (Print) (Online) Journal homepage: <https://www.tandfonline.com/loi/tbeq20>

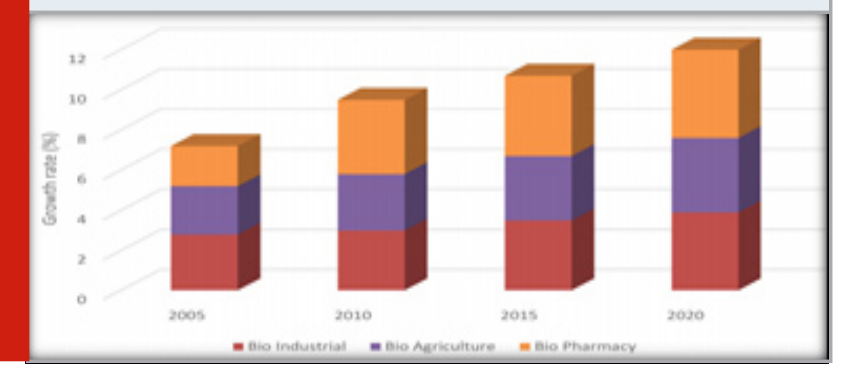

Biotechnology is an innovative, interdisciplinary discipline that covers a variety of disciplines, including agriculture, veterinary medicine, medicine, pharmaceuticals and the production of fine chemical products. It has become one of the key technologies for the transition to a carbonfree society and for solving important social challenges such as protecting health, providing foods and energy and protecting the environment. Professional networks such as the European Biotechnology.

\section{Covid-19 Pandemic Demonstrates The Power Of Biotech:}

The outbreak of the highly contagious coronavirus (now known as COVID 19) has started in the Chinese city of Wuhan. It then spread across the world, affecting several countries and endangering the lives of millions of people. The coronavirus (COVID 19) mainly causes respiratory infections SARS (severe respiratory syndrome) and MERS (Middle East respiratory syndrome). The World Health Organization (WHO) named the COVID-19 virus as the official name of the infection caused by this novel Coronavirus. The proposed name is based on the letters in the word "co" for aura, "vi" for virus and "d" for disease. While the COVID-19 pandemic has highlighted the importance of biotechnology and its industry, it is proving to be a huge challenge for the medical device industry. Scientists and researchers in the biotechnology industry were working with computer science to develop fast and intelligent test suites. Start-ups also have a great opportunity to develop / produce these rapid volume test suits.

Coping with a pandemic situation requires many doctors, nurses and paramedics. Frontline soldiers and biotechnology experts fighting COVID-19 are constantly working to develop vaccines that need protection before they can work in the lab. This outbreak shows a global shortage of personal protective equipment (PPE) such as face shields, scarves, gowns, goggles, gloves and masks. PPE is of paramount importance in preventing the spread of highly contagious viruses, especially in treatment centers such as hospitals and laboratories. The biotechnology and pharmaceutical industries must play an important role in addressing this global crisis. We also need government support.

According to India's biotech queen Kiran Mazumdar Shaw, "This is an opportunity to truly strengthen India's biotech industry. It is very important to move forward with vaccine production during the pandemic. In a larger way. Obviously, a lot of virus research Required". With the spotlight, the biotech industry is now starting to get attention. These impacts are felt, recognized and appreciated by all of us. There is no way to become a bioengineer. The term biotechnology is derived primarily from the Greek "bios" meaning "everything" that threatens life" and "technicos" meaning "human knowledge and skills". The main goal of the work undertaken by biotechnology or biotechnology researchers is to use new ideas and research methods to produce drugs, pharmaceuticals and vaccines with human therapeutic properties. Biotechnology has proven its importance as the savior of mankind in the 21 st century. 
Table 1.1 Biotech's Contribution towards Drugs

\begin{tabular}{|c|c|}
\hline $\begin{array}{l}\text { Hydroxychloro } \\
\text { quine }\end{array}$ & Approved as a treatment in mild cases and as prophylactic \\
\hline Favipiravir & $\begin{array}{l}\text { An oral antiviral drug, fast-tracked by Drug Controller General of India } \\
\text { Received Emergency Use Authorization for treatment of mild or } \\
\text { moderate infections. } \\
\text { The drug not approved in the EU or US. }\end{array}$ \\
\hline Remdesivir & $\begin{array}{l}\text { Gilead Sciences patented anti-viral drug, earlier tried on Ebola. } \\
\text { Hospital-only, Injectable drug. } \\
\text { Has Emergency Use Authorization for treatment of moderate to severe } \\
\text { COVID-19 patients. }\end{array}$ \\
\hline Tocilizumab & $\begin{array}{l}\text { Hospital only, Injectable drug originally used in patients with } \\
\text { rheumatoid arthritis. } \\
\text { Approved as an "off-label" drug for the treatment of moderate to severe } \\
\text { COVID-19 patients. } \\
\text { Works to counter the severe inflammation (Cytokine storm) that occurs } \\
\text { in some Covid-19 patients. } \\
\text { Clinical trials have shown reduced immune in inflammation. } \\
\text { Tocilizumab works when the immune response is already inflamed and } \\
\text { helps to arrest the impending cytokine storm, which affects other organ } \\
\text { functions. } \\
\text { Manufactured by Roche Pharma, marketed by Cipla under brand name } \\
\text { Actemra. }\end{array}$ \\
\hline $\begin{array}{l}\text { Itolizumab } \\
\text { (only } \\
\text { preliminary } \\
\text { results } \\
\text { available) }\end{array}$ & $\begin{array}{l}\text { Biocon's Hospital- only, Injectable drug earlier approved for the } \\
\text { treatment of Psoriasis. } \\
\text { Itolizumab works best when given to patients on non-invasive ventilator } \\
\text { support-before the immune response is hyperactivated and works to } \\
\text { delay or slow down cytokine storm. } \\
\text { Itolizumab \& Tocilizumab both work on controlling hyperactive } \\
\text { immune response and cytokine storm but differ in this timing. }\end{array}$ \\
\hline $\begin{array}{l}\text { Steroids } \\
\text { Dexamethasone }\end{array}$ & $\begin{array}{l}\text { The only drug too far to show striking impact on mortality. } \\
\text { Clinical trial on going-UK's RECOVERY Trials showed } \\
\text { dexamethasone can reduce death by one-third in patients with severe } \\
\text { Covid-19 infection who need oxygen therapy or are on ventilations. }\end{array}$ \\
\hline $\begin{array}{l}\text { Methylpredniso } \\
\text { lone }\end{array}$ & For use as an anti-inflammatory drug. \\
\hline $\begin{array}{l}\text { Low molecular } \\
\text { weight Heparin }\end{array}$ & To prevent blood clots \& thrombogenic response. \\
\hline $\begin{array}{l}\text { Antibiotics- } \\
\text { Azithromycin, }\end{array}$ & To dea \\
\hline
\end{tabular}

\begin{tabular}{|c|c|}
\hline Ivermectin & \\
\hline \multirow[t]{2}{*}{$\begin{array}{l}\text { Convalescent } \\
\text { Plasma } \\
\text { Therapy }\end{array}$} & $\begin{array}{l}\text { Approved as an "off-label" therapy and works best when given early on } \\
\text { in the treatment cycle. }\end{array}$ \\
\hline & Upcoming/New Drugs \\
\hline DRDO (In use) & $\begin{array}{l}\text { As the public results of } 2-D G \text { medicine efficacy are not yet available, we } \\
\text { trust the fact that DRDO had developed it and DGCI has approved it. On } \\
8^{\text {th }} \text { May } 2021 \text {, DRDO gave a statement about the efficacy of DRDO } \\
\text { Covid drug. The statement is as follows: } \\
\text { The patient who was given 2-DG medicine showed better and faster } \\
\text { improvement than the Standard of Care (SoC). DRDO Anti Covid drug } \\
\text { comes in powdered form and can easily be taken by dissolving in the } \\
\text { water. It treats the cells which are infected by the virus and avoids the } \\
\text { growth of virus }\end{array}$ \\
\hline Virafin & $\begin{array}{l}\text { Virafin is an antiviral drug that is injected under the skin. Significant } \\
\text { clinical and virological improvements were observed in moderate cases } \\
\text { when the drug was administered to Covid patients at an early stage. } \\
\text { Patients treated with Virafin were negative within } 7 \text { days, according to } \\
\text { the drug company. Virafin has also been shown to reduce the amount of } \\
\text { time patients need supplemental oxygen. The pharmaceutical company } \\
\text { states that pegylated interferon alpha-2b (PegIFN) Virafin is only } \\
\text { available by prescription from a healthcare professional and is designed } \\
\text { for use in institutions or hospitals. } \\
\text { Zydus Cadila's new drug "Virafin", which is considered successful in the } \\
\text { treatment of Covid patients, will soon be available in three districts of } \\
\text { Uttar Pradesh, namely Lucknow, Varanasi and Prayagraj. }\end{array}$ \\
\hline Baricitinib & $\begin{array}{l}\text { Eli Lilly, a US pharmaceutical company, granted additional voluntary, } \\
\text { royalty-free, non-exclusive licenses on May } 13 \text { to three other Indian } \\
\text { pharmaceutical companies - Reddy, MSN Laboratories and Torrent } \\
\text { Pharmaceuticals - Manufacture and distribution of baritinib in United } \\
\text { States. Rheumatoid arthritis treatments are used to treat patients with } \\
\text { Covid-19. } \\
\text { Lily states that Emergency Use Restriction by the Central Drug } \\
\text { Standards Control Organizations (CDSCO) of the Ministry of Health for } \\
\text { the use of varishichinibu and in combination with remdesivir for the } \\
\text { treatment of hospitalized patients with suspected Covid-19 or adults } \\
\text { confirmed to need oxygen for testing, invasive mechanical ventilation or } \\
\text { extra corporeal membrane oxygenation (ECMO). }\end{array}$ \\
\hline
\end{tabular}

Source: < https://www.cnbctv18.com/healthcare/covid-19-treatment-update-here-is-alist-of-all-drugs-used-in-india-their- pros-and-cons-6322301.htm> 
This happened most of the time after the biotech industry no longer had to deal with it. Lack of funds, shortage of manpower, unprocessed work etc. Now is the time to wake up and help make the world a better place to live in light that meets the expectations of ordinary people.

How Biotechnology Is Contributing To The Fight Against Covid-19?: Biotechnology plays an important role in contributing to the current state of the coronavirus. Much effort has been made to develop therapeutic responses to the virus. Bioengineers are using human cells and genetic mechanisms to study genetics and transfer this information to knowledge and vaccine discovery tools to advance their understanding of the mechanism virus.

o Diseases Testing, Treatment And Role Of Prevention By Vaccine: Basically, Contribution of Biotech Industry against covid-19 is an under: Covid-19 -control with the help of biotechnology-how?

\section{o COVID Tests:}

Diagnostic tests/RT-PCR (Reverse Transcription polymerase chain reaction)-: Diagnostic test or PCR or Reverse Transcription polymerase chain reaction is an innovative method based on DNA polymerase, an enzyme discovered by Western scientist, Spain Margarita Salas. This enzyme is capable of synthesizing DNA in vitro from short fragments of template genes, in this care from the viral genome. If diagnostic testing is performed by PCR, fragments of the pathogen's genetic material can be found. Analysis of respiratory samples from an infected person matches short viral gene fragments in vivo with PCR gene fragments. Thus, DNA polymerase starts to react and make multiple copies of that DNA fragment which can be taken back in this case, the result is positive, indicating that this patient has COVID-19.

Rapid test: The rapid COVID test is a type of diagnostic test. Rapid scans typically measure a viral antigen, a substance that directs the body to produce an immune response against an infection. Antigens, unlike antibodies, are produced by the immune system in response to signals from antigens. Staff trained in a variety of settings can perform COVID antigen testing rapidly.

o New Medicines: India has been the generics pharmacy to the world. But the coronavirus pandemic has unprotected deep responsibility lines in India's healthcare volume to pleasure people. These inadequacies originate from the usually poor status of public health substructure in India Participants therefore emphasized that in addition to emerging safe and effective drugs, India needs to invest in manufacturing personal protective equipment, scaling up oxygen supply, emerging new medical infrastructure and building a cohort of healthcare workers to ensure availability and resilience in the system. COVID second wave affects trial of some new drugs like following.

India likely to get at least 4 new Covid-19 vaccines by end of 2021:

Table 1.2 List Of Covid-19 Vaccines

\begin{tabular}{|c|c|}
\hline Name of & Specifications \\
\hline Covavax & $\begin{array}{l}\text { The Pune based Serum Institute of India (SII) manufactures the Oxford AstraZeneca vaccine as } \\
\text { "Covishield". However, it also produces a Covid- } 19 \text { vaccine based on the NVX-CoV2373 protein } \\
\text { under the brand name "covavax". The vaccine was developed American biotechnology company. SII } \\
\text { will do the same in India after Novavax obtains the necessary approvals for efficacy trials abroad. }\end{array}$ \\
\hline Hgc019 & $\begin{array}{l}\text { Not far from SII, Gennova Biopharmaceuticals is another company based in pune. The company has } \\
\text { developed India's first Covid-19 mRNA vaccine, named HGC019. }\end{array}$ \\
\hline Nasal vaccine & $\begin{array}{l}\text { Bharat Biotech's nasal vaccine candidate is currently in Phase I trials. According to the manufacture, } \\
\text { the BBV154 intranasal vaccine elicits an immune response at the site of infection (nasal mucosa). }\end{array}$ \\
\hline ZyCoV-D & $\begin{array}{l}\text { Zydus Cadila in Gujarat is producing an intradermal Covid-19 vaccine called ZyCoV-D it is India's } \\
\text { first locally developed DNA vaccine candidate and is currently being tested in children. }\end{array}$ \\
\hline Corbevax & $\begin{array}{l}\text { Biological } \mathrm{E} \text {, based in Hyderabad has developed a vaccine candidate called Corbevax, which is } \\
\text { currently in phase } 3 \text { clinical practice. }\end{array}$ \\
\hline $\begin{array}{l}\text { PTX- } \\
\text { COVID19-B }\end{array}$ & $\begin{array}{l}\text { Biological E also manufactures mRNA vaccine. The company has signed a licensing agreement with } \\
\text { Providence Therapeutics Holdings to manufacture a Covid- } 19 \text { mRNA vaccine from a Canadian } \\
\text { company in India. A vaccine called PTX-COVID19-B is currently being developed in Canada. }\end{array}$ \\
\hline Janssen & $\begin{array}{l}\text { Biological } \mathrm{E} \text { is also bringing Johnson \& Johnson's Covid-19 vaccine to India. An Indian company has } \\
\text { a contract to manufacture around } 600 \text { million doses of a vaccine called Janssen. Janssen is specifically } \\
\text { approved for use in the United States, European Union, Thailand and south Africa. }\end{array}$ \\
\hline Sputnik v & In India, six companies will produce the Russian Covid Sputnik V vaccine. \\
\hline Moderna & $\begin{array}{l}\text { The UN agency Strategic consultive cluster of consultants (SAGE) on immunization has issued } \\
\text { Interim recommendations to be used of the Moderna mRNA-1273 vaccinium against COVID-19 in } \\
\text { individuals aged eighteen years and older. }\end{array}$ \\
\hline $\begin{array}{l}\text { Pfizer- } \\
\text { BioNTech }\end{array}$ & $\begin{array}{l}\text { The Pfizer-BioNTech COVID-19 immunogen has not been approved or licensed by the U.S. Food and } \\
\text { Drug Administration (FDA). }\end{array}$ \\
\hline
\end{tabular}

Source: Covid-19 vaccines by end of $2021<$ India likely to get at least 4 new Covid-19 vaccines by end of 2021 | Details - Coronavirus Outbreak News (indiatoday.in)>

Development of vaccine: The coronavirus pandemic has transported to the front the possible of the scientific community and the private sector to develop and manufacture vaccines is a limited time frame.
Participants deliberated that during the initial stages of the pandemic. Indian vaccine companies were trying to import vaccine development technology and only product clinical development in india. But within a year, 
India has advanced a few vaccines indigenously. A few participants however emphasized that the regulatory system in India, in light of the pandemic, is not fully favorable for smaller firms to fast-track possible candidates, given lack of resources and a clarity of path, thereby constricting the scope of vaccine manufacturing and delivery in India.

They therefor e suggested that whenever the pandemic is controlled, Indian researchers, industry and government should assess the impediments to original discoveries, production and distribution and create approaches to overwhelmed them. India started vaccination against COVID-19 on January 16,2021 (143 days ago). As of 7June 2021, India had established a total of $236,198,726$ doses, including primary and secondary doses of currently accepted vaccines. Both vaccines were accepted for emergency use in India at the beginning of the program. Oxford -AstraZeneca vaccine brand manufactured by Covishield- Serum institute of India and nosevacin developed by Bharat Biotech.

In April 2021, the Government of India accepted the Russian vaccine Sputnik V (locally distributed by Dr. Reddy's Laboratories) as a third vaccine and began use in May 2021. Everyone has heard of Covishield, Covaxin and Sputnik V. However, there are many other Covid19 vaccine candidate currently being installed in India. People are talking about Covishield, Covaxin, Sputnik V. Three Covid-19 vaccine have been managed in India. But in fact, there are many other Covid-19 vaccines currently available in India by the end of this year, there will undoubtedly be six dozen vaccines in India. This narrows the gap between supply and demand and lowers prices.

\section{CONCLUSION IN TERMS OF POST COVID ERA}

Necessity and Opportunity For Biotech Sector: Biotechnology is one of the modules by which covid19 can be understood properly, treated and prevention can be taken by vaccines. Regarding the impact of COVID-19, biotechnology icon Kiran Mazumdar Shaw believes it is both necessary and an opportunity for the biotechnology industry to start seriously investigating this type of viral disease. The current situation shows the importance of preparing for unexpected epidemics such as the possibility of an outbreak. Kiran Mazumdar Shaw said the following factors are expected to further accelerate the development of the biotechnology field.

o Increasing interest in health and personal hygiene Promotion of production and research and development will inevitably increase the demand for reagents, media and serum. More laboratory drugs are needed due to growing concerns about environment and related regulations.

o Pandemics can shrink supply chain systems, especially because they are more dependent on other countries. India is becoming more autonomous and trying to develop better and more unique technologies. o India is a young country full of highly skilled resources and "Make in India" can also offer great opportunities for biotech companies and the tech industry.

o The biotechnology profession is very promising, biotechnology scholars not only achieve their research and innovation goals, but also contribute to the country, especially humanity.

o Thus, we can say that Biotech Industry act as a Boon against Covid-19 Pandemic.

\section{REFERENCES}

https://byjus.com/biology/what-is-biotechnology/

https://www.linkedin.com/pulse/biotechnology-itsimpact-todays-tomorrows-world-saveena-solanki

http://www.emro.who.int/health-topics/corona-virus/ about-covid-19.html

https://www.ibef.org/industry/biotechnology-hindia. aspx\#: : :text=The\%20Indian\%20biotechnology\%20 industry\%20amounted,\%25\%20from\%203\%25\%20 in\%202017.

https://pharmeasy.in/blog/how-can-we-survive-thesecond-wave-of-covid-19/

https://www.ibef.org/industry/biotechnology-india. aspx

https://www.biotecnika.org/2020/05/biotechnologistscovid19-pandemic-role-of-biotech-industry/

https://carnegieindia.org/2021/04/23/role-ofbiotechnology-in-india-s-fight-against-covid-19pandemic-event-7633

https://www.cnbctv18.com/healthcare/covid-19treatment-update-here-is-a-list-of-all-drugs-used-inindia-their-pros-and-cons-6322301.htm

https://en.wikipedia.org/wiki/COVID-19_vaccination_ in_India

https://www.indiatoday.in/coronavirus-outbreak/ vaccine-updates/story/india-get-new-covid-vaccinesend-2021-details-1811059-2021-06-04

https://www.healthgrades.com/right-care/coronavirus/ what-to-know-about-rapid-covid-testing

https://www.who.int/news-room/feature-stories/ detail/the-moderna-covid-19-mrna-1273-vaccinewhat-you-need-to-know?gclid=EAIaIQobChMIsIe y9SK8QIVyn4rCh1qKQeIEAAYASAAEgJdqPD_BwE https://www.pfizer.com/news/hot-topics/the_facts_ about_pfizer_and_biontech_s_covid_19_vaccine Post-COVID- Era: Necessity and Opportunity for Biotech Sector | Adamas University

\section{- REFERRED RESEARCH PAPERS:}

Donald K. Martin, Oscar Vicente, Tommaso Beccari, Miklós Kellermayer, Martin Koller, Ratnesh Lal, Robert S. Marks, Ivana Marova, Adam Mechler, Dana Tapaloaga, 
Polona Žnidaršið-Plazl \& Munis Dundar (2021), A brief overview of global biotechnology, Biotechnology \& Biotechnological Equipment, ISSN: (Print) (Online) Journal homepage: https://www.tandfonline.com/loi/ tbeq20

Dr. Sonali Joshi, a Leader in the battle against Covid-
19, Head of Department of Biotechnology, Fergusson College (Autonomous), Pune

Maria Gavrilescu (2010), Environmental Biotechnology: Achievements, Opportunities and Challenges, Dynamic Biochemistry, Process Biotechnology and Molecular Biology 4 (1), 1-36 @2010 Global Science Books 